\title{
Teacher Observations on the Implementation of the Tools of the Mind Curriculum in the Classroom: Analysis of Interviews Conducted over a One-Year Period
}

\author{
Susan Imholz ${ }^{1}$, Anthony Petrosino ${ }^{2}$ \\ ${ }^{1}$ Independent Author, West New York, NJ, USA \\ ${ }^{2}$ College of Education, University of Texas, Austin, USA \\ Email: susan.imholz@pepperdine.edu, ajpetrosino@mail.utexas.edu
}

Received February 23 $3^{\text {rd }}, 2012$; revised March 20 ${ }^{\text {th }}$, 2012; accepted April $3^{\text {rd }}, 2012$

\begin{abstract}
The following pilot study reports on teacher observations and reflections of implementing the Tools of the Mind curriculum in pre-k and kindergarten classrooms in an east coast urban school district in the US. The study followed five teachers over the course of a school year. Structured interviews were conducted with each teacher individually shortly after Tools of the Mind teacher training sessions took place. The analysis reports on themes that emerged in these conversations. Findings address; challenges the teachers faced in implementing the program, training issues, and the effectiveness of the program in supporting children's intellectual and social skills.
\end{abstract}

Keywords: Curriculum; Preschool Education; Early Childhood Education; Learning; Social Development; Self-Regulation

\section{Introduction}

The Tools of the Mind (hereafter Tools) curriculum is relatively new to the US. Its developers, Dr. Elena Bodrova and Dr. Deborah Leong, are based at Metropolitan State College of Denver, Colorado and have been working together on the Tools curriculum since 1993 according to their website (www.toolsofthemind.org). Over the past decade Dr. Bodrova and Dr. Leong have been successful in enlisting a number of school districts to adopt the program, as well as provide professional development training to teachers in those schools (Bodrova \& Leong, 2007). The Tools' website currently notes that the curriculum is being implemented in Colorado, Florida, Maine, Massachusetts, New Jersey, New Mexico, North Carolina, Oregon, Pennsylvania, Tennessee, Texas, and Washington ${ }^{1}$. With a little over a decade of use in public schools here in the US, there are still only a small number of studies that attest to its effectiveness and outcomes (Diamond \& Lee, 2011; Bodrova \& Leong, 2003, 2005a, 2005b, 2006; Barnett, Jung, Yaroz, Thomas, \& Hornbeck, 2008), and none have specifically addressed the concerns and experience of the teachers who are in the early phases of implementing the program.

The history of educational curriculum and pedagogy in American public education is nearing its bicentennial year since the establishment of public schools outpaced private schools in the late colonial era, circa 1840, and the publication of the McGuffey Readers - the first grade-level reading text books widely used in 19th century America. The evolution of the field is marked by many milestones. Creation of a robust educational publishing industry and the creation of the educational software industry utilizing multiple pedagogical approaches are two examples of significant innovations. The portfolio of curriculum content for consumption by K-12 schools continues to

${ }^{1}$ www.toolsofthemind.org accessed 06/06/11. grow. However, only a subset of these educational materials represent design innovations which embody and reflect our growing understanding of cognitive and emotional development, or advances in our understanding of models of mind.

To illustrate this concretely, let's use the metaphor of the evolving automobile. If we compare and contrast a 1959 Ford with today's smart cars we can agree that both are forms of transportation which convey passengers from point A to point B. By design, smart cars are functionally more complex, more fuel efficient, are engineered to provide navigational direction and are sensitized to obstacles in their path, as well as being designed to protect occupants from a crash with special features. In short, the smarter car embodies collective advances in engineering technologies across disciplines and these are advances that passengers can see, touch, and feel. Most of us are witnessing and participating in this cultural evolution because automobiles are ubiquitous. By contrast advances in K-12 educational curriculum are not as easily understood or appreciated because the experience of going to school is uniquely that of the student-parents are onlookers who get to participate in the choice of curriculum materials only if they are willing to become active members of a parent/teacher association, or School Board committee. Family members are also observers of curricular change to the extent that they are actively involved in monitoring children's homework (Scott-Jones, 1995; González, Andrade, Civil, \& Moll, 2001; Van Voorhis, 2003).

A brief recap of how changes in our models of mind are reflected in major milestones in curriculum materials over the past century helps to put the Tools of the Mind curriculum into perspective $^{2}$. Starting with the late 18 th century and early 19th century view of the child, schooling emphasized the study of religious texts, but home instruction also included reading,

${ }^{2}$ See: Michael Fullan (2001). The new meaning of educational change. New York, NY: Teachers College Press. 
writing, the Greek philosophers and mathematics. The corresponding model of mind that directed this choice of materials assumed the child needed moral guidance to mature as a productive member of society (Wishy, 1972). The accepted thinking about children's character was that they were born morally corrupted, and needed to be civilized through moral education first and foremost. The first inter-state association of teachers to rigorously advocate for early childhood education was The American Institute of Instruction, formed in Boston in $1830^{3}$. The Institute published one of the first periodic journals on teaching - the American Journal of Education. Many articles were dedicated to the importance of establishing early childhood education for all communities, regardless of class and wealth. Early Journal issues give first-hand accounts of how teachers struggled with making the transition from a model of crooked minds to that of the tabula rasa-the impressionable mind, then the developmental mind-the mind that grows to maturity in phases ${ }^{4}$.

The birth of the child study movement in the mid to late 19th century is often attributed to G. Stanley Hall. In terms of its impact on curriculum however, John Dewey most notably exemplified its ideas in practice. Dewey promoted experiential education that would enable children to learn theory and practice simultaneously. A modern day example of this is the practice of teaching elementary physics and biology to students while preparing a meal (Barron et al., 1998). At Dewey's lab school at Teachers College at Columbia University in the early 1900 's, children built objects in wood working shops, they cooked meals, stitched and wove cloth, and generally practiced skills that adults engaged in as a form of parallel play which conveyed to children that they were engaging in socially meaningful activities that were more exploratory than exploitive work chores. Dewey also acknowledged Friedrich Froebel's significant contribution to the design of infant and nursery school toys (aka Froebel gifts) ${ }^{5}$ and suggested the US model primary curriculum after Froebel's kindergarten ${ }^{6}$. While moral and ethical teachings were still considered important, defining age appropriate content and subject matter became the focus of educators. Moreover, the internal world of psychological development was beginning to exert itself as the determining factor in the design and production of books for public and educational consumption.

As cognitive psychology took root as theory taught in schools of education, teachers learned about stages and phases of the child's mental growth in their training. These ideas were further refined by Jean Piaget in observations and research ${ }^{7}$. The notion that conceptual changes in thinking were closely allied with physical maturation was another milestone which influenced curriculum development. Montessori, Waldorf schools and the Reggio Emilia system all evolved in tandem during the

${ }^{3}$ http://en.wikipedia.org/wiki/American_Institute_of_Instruction accessed 03/ 30/11.

${ }^{4}$ Infant Schools, American Journal of Education online, June; 3, 6 (1828); Education of Infant Children, American Journal of Education online July; 3 7 (1828); Pestalozzi's Letter on the Education of Infants, American Journal of Education online, March; 1, 2 (1830); Education of Infants-A case study American Journal of Education online, March; 1, 2 (1830); Address to the National Teachers Association, American Journal of Education online, June 43 (1866).

${ }^{5}$ See http://www.froebel.org.uk for the history of Froebel and his method.

${ }^{6}$ Dewey, J. (1990) The School and Society \& The Child and the Curriculum Chicago, IL; University of Chicago Press, centennial edition, p.116.

${ }^{7}$ See http://www.piaget.org/aboutPiaget.html for a full index of his writings. Accessed 04/02/11. early to mid 20th century under the prevailing belief that children are formed in large part by their early life experiences. While the philosophy of teaching varied among the three pedagogues above, they all shared a special attention to detail in the design of learning environments and created rich imaginative play spaces for children in the early primary grades.

During the second half of the 20th century experimental psychology began to influence academic thinking with cognitive information processing models of mind (Broadbent, 1958; Newell \& Simon, 1972). These theories focused on the atomistic analysis of how the brain acquires and processes new information, and shed light on how short term memory and long term memory were two different but overlapping activities of the brain; repetition and reflection being key to remembering facts and figures long enough to do well on a test. The information processing model of mind resulted in a renaissance of workbooks for every school text book, along with a resurgence of repetition and drill for K-12 education.

As theories of instruction began to evolve (Bloom \& Krathwohl, 1956; Bruner, 1960, 1966, 1996; Kalantzis \& Cope, 2008) curriculum choices multiplied, each reflecting different models of mind with the added dimension of using new media as a delivery system for instruction. In 1995, Tyak \& Cuban wrote that the idea of steady progressive educational reform had met its end in the $1970 \mathrm{~s}^{8}$. Perhaps another way of saying this is that the pluralistic choice of curriculum that sprang into existence over the latter part of the 20th century has made it more difficult for school administrators to convince parents and their communities that there is only one way forward in the name of education progress.

Historically, we can see schools have vacillated between pedagogy that offers highly structured, or drill and practice curriculum emphasizing the mastery of content, with seemingly less structured constructivist child-centered learning environments that value community building and social skills as much as the development of academic skills (Hmelo-Silver, Duncan, \& Chinn, 2007). This tension still lies at the crux of curriculum choice for school administrators, especially for pre-k and kindergarten classrooms. Setting aside the No Child Left Behind $\mathrm{Act}^{9}$ as a factor influencing decision making, education leaders need to analyze and interpret educational research about curriculum design just as medical professionals, legal professionals and engineers re-evaluate their practice relative to new data.

One way of defining progress that informs curriculum choice is to pay close attention to cross disciplinary research on the evolving understanding of mind from multiple perspectives: cultural, psychological, cognitive and neurobiological. The Tools program is based primarily on Vygotsky's (1986) ideas about the use of play as a catalyst for psychological and cognitive growth; however neuroscience research can also be cited for supporting the approach the Tools has developed. Neuroplasticity tells us that individuals are engaged from infancy onward in a unique experiment in scaffolding meaning making, one sound, one interaction, one image at a time (Pascual-Leone et al., 2005; Doidge, 2007; McEwen et al., 2011).

The main distinction of the Tools program from other pre-k curriculum is that it offers a more complicated model of mind

${ }^{8}$ Tyak, D. \& Cuban, L. (1995). Tinkering toward public school reform: A century of public school reform. Cambridge, MA: Harvard University Press p. 13.

${ }^{9}$ No Child Left Behind Act, legislation adopted by the US Congress in 2001 See PL 107-110, www2.ed.gov/lsec/leg/esea02/index.html. 
in addition to addressing classroom organization, management, and curriculum materials. This is an important aspect of the program and its successful adoption by schools. It's also worth noting because it represents a qualitative change in the design of classroom curriculum much the way smart cars outclass the 1959 Ford under the hood. It is for this reason that teacher observations in the implementation of the curriculum is well worth studying. Our pilot study formally begins a dialogue about how teachers experience and view the impact of the Tools program in their classrooms and their professional development, in addition to suggesting future directions for research.

\section{Study Rationale}

The relationship between preschool curriculum and later school success has been studied by Marcon (2002) with significant findings. Over a period of five years, Marcon tracked the academic progress of more than 300 children from an urban school district that had been exposed to three different types of preschool curriculum; child-initiated, academically oriented or directed, and a combination of the two. The results showed that preschool curriculum models did have an influence on children's later school achievement; students who had been involved with child-initiated curriculum had higher grades, and performed consistently better than the two other peer groups on academic tasks as they aged into and out of the elementary grades. What this tells us is that developing an internal locus of control and sense of agency in carrying out academic tasks matters, and it matters at a very young age. This appears to be an internal psychological disposition according to many educators, and very few public schools have adopted pre-k curriculum that address this goal in a serious way.

Enter, the Tools of the Mind curriculum. As mentioned above, Bodrova and Leong developed the Tools program in the 1990s and have been the sole medium of its dissemination; they are also evaluating the program (2001). Barnett et al. (2008) noted that “while child-centered, Tools emphasizes the teacher's role in guiding and supporting the child's learning... it does not fit neatly into frameworks that classify curricula as teacher-directed or child-initiated, child-centered or content-centered, and academically-focused or socialization focused” (p. 300). The program is highly structured for teachers, while at the same time emphasizes active participation in play for young students. In a recent journal article on educational media Verenikina (2010) observed that Vygotsky claims the prize as the most cited author in a review of current research. Although new to media studies, many in the field of education have long appreciated Vygotsky for the sociohistorical nature of cognitive growth and language development that he proposed, in contrast to Jean Piaget's more stage-stepped model of internal cognitive growth. Pea (2004) succinctly described the differences this way: "as Vygotsky would have it, psychological development progresses from an interpsychological to intrapsychological plane” (p. 426), i.e., learning precedes new internal categories to think with. Piaget surmised the opposite; that internalized construction of new schema forged by the individual makes new learning possible. The two theorists examine human development from different perspectives, Piaget through conceptual change, and Vygotsky (1986) through semiotic analysis of the socio-cultural environment the society provides. Wertsch (1985) portrays the three themes at the core of Vygotsky's theoretical framework as an analytical technique: 1) a reliance on a genetic or developmental method; 2) the assumption that higher order mental processes in the individual have their origins in social processes and activities; 3 ) the exhortation that mental processes are only understood through the lens of the cultural tools and signs that mediate them. Vygotsky's ideas have been widely read in academia, and found enthusiastic reception in the application and design of software environments for middle, secondary school, and adult populations (Papert, 1980; Collins \& Duguid, 1989; Papert \& Harel, 1991; Lave \& Wenger, 1991; Scardamalia \& Bereiter, 1991; Schauble \& Glaser, 1996; Sherin et al., 2004; Brown, 2006).

\section{Description of Tools of the Mind}

The Tools curriculum is designed to promote executive functions and self-regulation as learned behaviors that can be facilitated. Applying Vygotsky's theory through the use of 20th century media - books, flash cards, puppets, and scripted drama activities-presents special challenges for teachers who are the interpreters and facilitators of the child's experience of the program and its highest aims. First, as agents of change the Tools materials themselves do not embody the process oriented goals of their use. Secondly, fully embracing the Tools curriculum may involve discarding previously held models of mind and psychological development by teachers. Purposeful play is at the center of classroom learning - this may appear to be a step backward for both parents and teachers who have been led to believe reading and writing readiness are paramount goals for pre-k and Kindergarten. Daily activities promote self-regulatory behaviors in children not as a strategy, but as the primary goal of education. How this is communicated to inquiring parents may create some awkward moments. The concept of selfregulation is easily mistaken for behavioral compliance by seasoned educators. In the past curriculum did not address selfregulation directly, this issue was more often considered a classroom management topic-in other words, it was the teacher's responsibility to regulate students. Teachers simply waited for executive functions to emerge of their own accord with the arrival of "the age of reason" (Lowenfeld \& Brittain, 1975; Piaget, 1957, 1975).

The Tools curricula has shown that when self-monitoring is practiced, much the way we exercise our other muscles to improve our overall physical health, the child's ability to take direction, collaborate, and cooperate with peers is enhanced (Bodrova \& Leong, 2003, 2005a, 2005b, 2006; Barnet et al., 2008). These are internal attributes that are crucial to the child's later success in the primary grades, and sense of agency as Marcon's and Brown \& Campione’s (1994, 1996) research indicates.

There is a prescribed method for organizing the Tools classroom using several different activity centers along with proprietary reading texts. The cost of adapting a well furnished pre-k or kindergarten class to a Tools classroom is approximately $\$ 1000$ - $\$ 1500$. The greatest hurdle in the transition is conveying the curriculum to teachers who are, in many instances, taking on the tasks of becoming a Tools teacher by decree from above and who bring with them a host of their own ideas about how to teach early childhood education. There are over 40 activities in the Tools curricula that address literacy and writing skills, math, science, and drama play. A comprehensive description cannot be provided here, but the following three 
examples of Tools activities are discussed in the data and analysis sections, so an explanation will be helpful ${ }^{10}$ :

Buddy reading: A main feature of literacy skill building that incorporates reflective and self-monitoring activities. Children work in pairs; taking turns reading from a book and listening.

Symbolic mediators: Cue cards, graphic organizers, finger puppets with special roles and messages, and games designed to help young children transition from one activity to another, or assist in enrolling them into play characters.

Play plans: The first writing activity of the day, a kind of work contract the child creates, serves as plan that will guide drama play activities that the child will engage in for the day. The student and teacher conference once a week to review the plans.

The current study adds to the literature on the Tools of the Mind program by focusing on the teacher's experience of learning and teaching the curriculum. Just as multiple opportunities for children to reflect on their work and play in the classroom are built into the Tools activities as a means of stimulating critical thinking, inviting teachers to reflect upon their own appropriation of the Tools curriculum as instructors might harbor insights and indicators of the success of the program in its implementation. With this in mind, the researchers followed 5 teachers through the 2009-2010 school year to listen closely to the struggles, issues, and triumphs that were arising in their classrooms.

\section{Methodology}

A structured interview with teachers was chosen as the data collection method most appropriate to appraising the new curriculum roll-out. Information was solicited from teachers through a directed line of questioning or Socratic dialogue, with the goal of drawing out the teacher's thoughts and feelings, dispelling the notion that there are right and wrong answers. Transcripts of interviews were analyzed for themes and issues. The questions were also used as a heuristic schema in the analysis of the qualitative data. Additionally, the study structure gave the teachers an opportunity to reflect on what they were seeing and doing over and above what was required of them in the training program. Three of Knowles (1980) andragogical tenants are inherent in the design framework. They are: 1) adults learn best when they are involved in the planning and evaluation of their instruction; 2) experiences, good and bad, provide the basis for learning activities; 3) adult learning is problemcentered rather than content-oriented. There were approximately 20 - 25 teachers involved in implementing the Tools of the Mind curriculum in pre-k and Kindergarten classrooms in the school district; 5 of these teachers were chosen to participate in the study. Three interview questions were asked of the teachers at each of the three interview sessions scheduled in the fall, spring, and early summer. The interviews took place within 1 - 3 weeks after Tools of the Mind training sessions had been conducted, so that this experience would be fresh at hand. The interviews lasted approximately 45 - 50 minutes. The three interview questions asked were:

1) What are the challenges of implementing the Tools of the Mind program in your classroom, and what are your suggestions for improving training?

2) What is the program contributing to your own professional

${ }^{10}$ See the manual: Bodrova, E. \& Leong, D. J. (2007). Tools of the Mind: The Vygotskian approach to early childhood education. development as a teacher?

3) What behavioral and cognitive/academic changes are you seeing in your students over the academic school year?

\section{Study Description}

\section{Adoption of Tools of the Mind by School Administrators}

The adoption of the Tools of the Mind program in the New Jersey school district where the study took place was undertaken by the administration and school board in 2008, and launched during the 2008-2009 school year with the expectation of doing three things:

1) Standardizing the experience of pre-k and kindergarten for all students across the district, and enhancing kindergarten instruction by going from a $1 / 2$ day to full teaching day.

2) Acknowledging the development of social skills and selfregulation as a primary (versus secondary) goal of the pre-k and kindergarten experience, on par with the learning of academic skills.

3) Increasing the school readiness and self-regulatory behaviors of young children so that they would be better prepared to excel academically in the early primary grades.

\section{The School Environment}

Description of the city and school district: The study was conducted in an eastern seaboard city of approximately 50,000 according to the 2010 census, located near the New York City metropolitan area. The school district serves approximately 2000 students. The following profile presented is taken from 2010 census data: The racial makeup of the city is $83 \%$ White, 3.1\% African American, 0.16\% Native American, 4.9\% Asian, and $6.3 \%$ Hispanic. The median income for a household in the city as of the 2010 census was $\$ 105,710$ while the median income for a family was $\$ 130,068$. A growing population of the city is affluent; however, $32.5 \%$ of housing in the city is owner-occupied, while $67 \%$ is renter-occupied. Over the past six years, four new K-6 private schools have opened to compete with the local public school system.

\section{Choice of Subjects}

Convenience sampling was used for the selection of the 5 teachers in this study. Selection was assisted by the district Superintendent's office and Director of Child Development, who were overseeing the implementation of the new curriculum project. The subjects in this study were interviewed three times over the course of the 2009-2010 school year. Of the five teachers, three were pre-k instructors, and two were kindergarten teachers. All were in their second year of teaching the Tools curriculum.

The subject group, all women, represented a varied spectrum of backgrounds and skill level. Of the five the teachers the range of years in the profession was; 33, 13, 7, 7 and 4 years of teaching in pre-k, kindergarten, and early primary grades. All had been exposed to other curriculum programs (Creative Curriculum, and arts based pre-k and kindergarten curriculum) at some point in their careers. All five teachers had college degrees, and their first choice of a profession was teaching. They were all certified to teach pre-k and early childhood education according to New Jersey state standards. 


\section{Thematic Analysis of Interview Data}

Structured interview transcripts were analyzed for themes and issues. The themes that emerged were categorized in accordance with the three questions asked. Three main subcategories of issues emerged in this analysis for each question (See Table 1).

\section{Data Summary}

\section{Question 1-What Are the Challenges of Implementing the Tools of the Mind Program in Your Classroom, and What Are Your Suggestions for Improving Training?}

\section{Training Issues}

The training sessions themselves were given high praise by most of the teachers. There was a notable tendency for teachers to complement the trainers and support staff about preparation of materials needed for the training sessions, and the amount of thought and effort that was being expended. The teachers uniformly agreed that active participation in the training sessions (where activities were assigned for teams of teachers to work on and then present findings/activities) was preferable to lecture delivery of subject matter. Modeling how to conduct and structure new curriculum being introduced, and having the chance to model activities themselves with feedback was also a preferred method of conducting training activities.

The Tools of the Mind website, its teacher resources, and its accessibility 24/7 also got high praise from two of the five teachers.

All five teachers struggled with balancing their need for mastery of the new program content, with reflecting on the program's impact on their students-in the researchers' opinion, this was in part a linguistic problem. In other words, their Tools training did not address their own internal experience of conceptual change brought about by the adoption of the new curricula sufficiently for them to be able to articulate their discomforts in terms of epistemological change. Another way of viewing this issue is that the Tools program training may be overly centered on the child's experience, rather than the teachers' experience of learning the method. Framing the teachers' disorientation and worries as a natural result of their own

Table 1.

Interview questions and dominant themes.

What are the challenges of implementing the Tools program?
- Training issues
- Ethical issues
- Classroom challenges
What is the program contributing to your own professional development?
- Enhancing classroom management skills
- Enhancing classroom instruction skills
- Program addresses multiple learning styles
What behavioral and cognitive changes are you seeing in your students?
- Fewer classroom behavioral problems
- More collaborative behaviors
- Higher level of verbalization and communication among children

learning process as they move toward a more complex model of mind would have helped them to consider their issues as value-added contributions to the process, and would in turn consign higher value to their own learning.

Finally, the lack of ongoing scheduled opportunities for sharing ideas and to talk with other teachers within the school system who were also involved in the project was an issue raised by four of the five teachers in many contexts over the course of the year, many times.

\section{Ethical Issues}

An ethical dilemma relative to integrating old teaching methods with the new curriculum presented itself for one of the five teachers in particular. The point of contention was resolving the readiness level needed or expected of children in first grade, with the level of content knowledge about reading and writing that the new Tools curriculum was providing for kindergarteners. Struggling with this issue resulted in sleepless nights. "This has real consequences for kids", the teacher stated, "some parents have approached me and said 'I feel like my kid isn't getting what they need and isn't going to be ready for first grade,"'.

By the end of the year the issue had resolved itself; this teacher began recognizing that the more process oriented classroom activities that the Tools program provides had in fact resulted in an increase of functional skill levels across the board in all of her students, and, even though the students did not all share the same uniform level of content information (which her old teaching method provided) she was satisfied that the children as a group were ready for first grade.

\section{Classroom Challenges}

The Tools of the Mind curriculum does require that teachers learn a new way of documenting student progress. Keeping up with the amount of new note taking required was a challenge for all of the teachers, and some readily admitted that they were falling behind. Two teachers questioned the purpose of constant documentation of student activities, with the complaint that taking notes was interfering with their ability to interact with students. Fitting all of the daily activities suggested into the school day posed scheduling problems for at least 2 of the 5 teachers. By year end, this issue was less pressing as the teachers' mastered new learning activities that had been introduced during the year.

There was also resistance to becoming fully involved with drama play by two of the five teachers. Reasons given were that the play scenarios offered in training were too complicated for the children to act out, and, drama play was the activity viewed as most expendable in order to fit in another activity center. From the researchers' perspective, this appeared to be an issue of not fully understanding the theoretical bridge between personal and formal knowledge that the Tools program strives to build through drama play. These are training issues. In this particular instance, one's model of mind clearly determines how you set priorities in the classroom, and how teachers integrate new information with old.

\section{Question 2-What Is the Program Contributing to Your Own Professional Development as a Teacher?}

\section{Enhancing Classroom Management Skills}

Four out of the five teachers agreed that the Tools program 
was enhancing their professional development by giving them a more structured approach to classroom management (their terms). One of the interesting revelations expressed by one teacher was a growing awareness of how much she had been doing for her students, as opposed to allowing them to do things for themselves without her hovering assistance. With this new insight, she planned on backing off from being an aggressive interventionist. In her own words, "I realized how much I was doing for them-I think I was unaware of how independent they could be".

\section{Enhancing Classroom Instruction Skills}

Four of the five teachers also agreed that the Tools program was providing them with new activities for their arsenal of teaching techniques. One teacher felt as if she had already acquired many of the Tools program activities in principle, for example, use of mediator cards as behavioral prompts and puppet plays as a way of transitioning from one activity to another. On the other hand she did recognize that the Tools curriculum was exerting its influence on the children's social behavior in very positive ways.

A perceptive observation from the most senior teacher was that the Tools curriculum had succeeded in blurring the boundary between what the children considered play and work in her classroom. In her own words, "I'm not hearing-'Mrs. G-I'm done with my work, can I go play?'-anymore”.

\section{Program Addresses Multiple Learning Styles}

It was noted by two of the five teachers in the interviews that the Tools curriculum truly provides for multiple learning styles, the visual learner, the auditory learner and the haptic ${ }^{11}$ learner in a way that previous curriculum materials used did not. The visual learner gets to draw and symbolize, the auditory learner is engaged through buddy reading and role play, and the haptic learner gets to act out his or her ideas in dramatic play.

\section{Question 3-What Behavioral and Cognitive Changes Are You Seeing in Your Students?}

\section{Behavioral Change}

All five teachers reported fewer classroom behavior problems during the third and last interview of the school year. Reasons given included the following:

- "The kids show more patience with one another... there aren't as many classroom squabbles”.

- "They have respect for one another".

- "I do not have to raise my voice to get [the classes] attention”.

- "Kids are using language more to resolve conflicts... where they use to resort to hitting or shoving each other".

- "They follow rules better".

- "There is calmness to the classroom now".

It is interesting to note that many of the improvements cited by the teachers are functional proficiencies describing the young students taking on greater responsibility for their learning, as well as showing a heightened level of engagement in classroom activities. These behaviors definitely fall under the category of self-regulation and greater self-reflection.

\footnotetext{
${ }^{11}$ The term haptic was authored by Victor Lowenfeld in his observations of how children approach artistic and creative problem solving. See: Lowenfeld, V. and Brittain, W. (1975) Creative and Mental Growth. New York, NY: MacMillan, 8th edition.
}

\section{Cognitive and Academic Change}

Teachers' observations suggested that the teachers did see cognitive changes in students' abilities, but not all of the teachers were able to articulate the relation between the Tools curriculum activities and the emergence of new skills and abilities on the part of the students:

- "[The children] can be self-monitoring in terms of moving from activity to activity center over the course of the day”.

- "Best group of students ever in [my] seven years of teaching... by far my most independent and brightest group, but I don't know if it has anything to do with the Tools program”.

- "They follow rules better".

Here again, training sessions that set forth a clear framework for thinking about conceptual changes in one's developmental model of mind may be the missing link in making these connections for teachers.

\section{Cognitive and Academic Change}

Overall, teachers reported a higher level of verbalization and communication among students:

- " "[The children] express their feelings when interacting with one another now... [for example] 'you are making me feel sad' which I've never heard before”.

- "Their attention span is greater".

- "They are writing three or four sentences-all their own ideas. They may be spelling words phonetically, so it's not perfect writing, but they've got the idea that what they say and think matters".

- “They are more comfortable explaining and talking about what they are doing in the classroom - in drama play and in buddy reading”.

The observed increase in the student's verbalization skills and communication with each other goes hand in hand with the perceived increase in collaborative behaviors among children. What is implied here is that academic achievement may follow from these behaviors.

\section{Discussion and Analysis}

\section{Teacher Observations Confirm Empirical Findings}

The interviews suggest that the implementation of the Tools of the Mind program is demanding according to teachers' selfreport. Even so, all five subjects in the study report achieving a level competence and mastery of the curriculum that is providing them with a sense of accomplishment. At the conclusion of the school year, two of the five teachers mentioned that they were thinking about applying to the Tools of the Mind Endorsed Teacher Program which would give them certification status. One cannot discount the bias, or halo effect of the researchers in this small study. As interested observers appearing on a regular basis throughout the year, we were repeatedly reinforcing the idea that what teachers have to say is important and worth documenting. Yet, what they observed as cognitive and social benefits, i.e., fewer classroom behavioral problems, more collaborative behaviors, a higher level of verbalization and communication, dove-tails with the empirical research findings of Barnett et al. (2008). This 2008 study compared Tools classrooms and a control group on a number of parameters. ECERS scores (the Early Childhood Environmental Rating Scale) and SELA scores (Support for Early Literacy Assessment) were among the tests used for assessing differences be- 
tween the classes. Results showed the Tools classrooms attained higher overall levels of quality: "the [higher] ECERS scores were particularly evident on the Language and Reasoning Activities, and [classroom] Interactions subscales” (p. 310).

The concept of blurring work and play which the Tools program fosters-noted by one teacher-maybe key to the formation of an internal locus of control and self-regulation. The melding of personal knowledge and formal knowledge could be the lynch-pin to keeping children engaged in their own learning process as they move through elementary school. It is the sense of separateness, the self-imposed distinction that academic study is for someone else, which forms the crack in the armor of identity marking the beginning of the end of a successful academic career.

\section{Sharing Good News}

Teachers report overall quality of the training was good, but inter-school communication was poor. A gulf still appears to exist between the theoretical understanding of Vygotsky's work, his model of mind, and how it relates to academic achievement and the growth of self-regulatory behaviors in children. Important individual differences in the teachers' ability to articulate the impacts and benefits of the program existed among the five subjects. Therefore, providing an ongoing forum for all pre-k and kindergarten teachers across the district to share their experiences on a regular basis together, and opportunities for peer-to-peer mentoring could be very beneficial to achieving superior mastery of the Tools curriculum allowing best insights to be shared. If a distinguishing characteristic of the Tools program is its model of mind, our study suggests that there were lost opportunities to discuss and use that model as a touchstone for understanding the "how" and "why" of day to day curriculum activities for instructors. This can be easily addressed, but first needs to be recognized as a problem. Ultimately, it is teachers and not curriculum materials that are the transmitters of pedagogical culture.

The two kindergarten teachers in the study also expressed the desire to reach out to first grade teachers and communicate what they were doing to facilitate a smooth transition for the children from the Tools of the Mind curriculum program to the new first-grade curriculum. If this were to become a formalized activity that occurred at the beginning of the school year, it would be a way to share the good news about the goals and objectives of the Tools program across grade levels. Any academic benefits that have accrued to young students in the Tools pre-k program may be diluted or lost if the elementary-grade teaching-staff is left in the dark about the curriculum. For example, the unique hieroglyphs used in Tools' writing tasks may appear as gibberish to the uninitiated elementary instructor-is it fair to young students to be put in the position of being their own advocates in regard to building upon previous learning experiences?

\section{Conclusion}

The Tools of the Mind program is still relatively young and its benefits are still being measured and assessed as children advance from pre-k and kindergarten through the primary grades. One could argue that the program's true value is to be found in what children accomplish academically in second, third, and fourth grade. The teacher observations and reflections in this study give us new insights into how the ongoing integration of the Tools program can be enhanced at this site, thereby improving the educational experience for students. The scale, scope, and method used in this work does not allow for generalizing its findings. Nonetheless, lasting education changes in teaching practice have to be anchored in good administrative practices and supportive work environments. What we have brought to light can best be categorized as lapses in planning and professional development activities - and these are easily remedied.

More importantly, we introduced the teacher as collaborator whose learning process constitutes a dynamic form of parallel play in the appropriation of the Tools curriculum with their students. We know from extensive research (Goe \& Stickler, 2008; Hanusek et al., 2005; Darling-Hammond, 2000) that teacher quality is the primary factor in whether a child advances academically in almost any classroom. Extending to teachers the same attributes of mind that are highly valued for young students-i.e., the primacy of the social construction of knowledge-is central to the evolution of the education ecosystem. Regardless of research methodology, a systems approach to the study of education change and innovation enhances the application and usefulness of academic research by acknowledging that true knowledge is not gained from simple observation and measurement of things alone, but in finding the connections between things that lead to a more in-depth understanding of learning environments.

Suggestions for continued research include: 1) comparing a problem-centered vs content-oriented approach to Tools teacher training in the second year of the program implementation, with student academic outcomes; 2) knowing that adults learn best when they are involved in the planning and evaluation of their instruction, incorporating ongoing discussions of epistemological change among Tools teachers in future research evaluation rubrics to better assess conceptual transformation.

\section{Acknowledgements}

We thank the teachers and principals who generously gave time and effort to this project freely.

\section{REFERENCES}

Barnett, S., Kwanghee, J., Yaroz, D., Thomas, J, Hornbeck, A., Stechuk, R., \& Burns, S.(2008). Educational effects of the Tools of the Mind curriculum. A randomized trial. Early Childhood Research Quarterly, 23, 299-313. doi:10.1016/j.ecresq.2008.03.001

Barron, B., Schwartz, D. L.,Vye, N. J., Moore, A., Petrosino, T., Zech, L., \& Bransford, J. D. (1998). Doing with understanding: Lessons from research on problem and project based-learning. The Journal of the Learning Sciences, 7, 271-311.

Bloom, B. S., \& Krathwohl, D. R. (1956). Taxonomy of educational objectives; the classification of educational goals by a committee of college and university examiners. Handbook I: Cognitive Domain. New York, NY: Longmans, Green.

Bodrova, E., \& Leong, D. (2001). Tools of the Mind: A case study of implementing the Vygotskian approach in American early childhood and primary classrooms. International Bureau of Education.

Bodrova, E., \& Leong, D. J. (2003). How play rich environments foster literacy high level play. Early Childhood Today, 22-25.

Bodrova, E., \& Leong, D. J. (2005a). Uniquely pre-school: What research tells us about the ways young children learn. Educational Leadership, 63, 44-47.

Bodrova, E., \& Leong, D. J. (2005b). Self-regulation: A foundation for 
early learning. Principal, 85, 30-36.

Bodrova, E., \& Leong, D. J. (2006). The development of self-regulation in young children: Implications for teacher training. In M. Zaslow, \& I. Martinez-Beck (Eds.), Future directions in teacher training (pp. 203-224). New York: Brooks-Cole.

Bodrova, E., \& Leong, D. J. (2007). Tools of the Mind: The Vygotskian approach to early childhood education (2nd Ed.). Columbus, $\mathrm{OH}$; Merrill/Prentice Hall.

Broadbent, D. (1958). Perception and communication. Amsterdam, NL: ElsevierScience. doi:10.1037/10037-000

Brown, A. L., \& Campione, J. C. (1994). Guided discovery in a community of learners. In K. McGilly (Ed.), Classroom lessons: Integrating cognitive theory and classroom practice. Cambridge, MA: MIT Press/Bradford Books.

Brown, A. L., \& Campione, J. C. (1996). Psychological theory and the design of innovative learning environments: On procedures, principles, and systems. In L. Schauble, \& R. Glaser (Eds.), Innovations in learning: New environments for education (pp. 289-325). Mahwah, NJ: Erlbaum.

Brown, J. S., Collins, A., \& Duguid, P. (1989). Situated cognition and the culture of learning. Educational Researcher, 18, 32-42.

Brown, J. S. (2006). New learning environments for the 21st century: Exploring the edge. URL (last checked 5 January 2012). johnseelybrown.com/Change\%20article.pdf

Bruner, J. (1960). The process of education. Cambridge, MA: Harvard University Press.

Bruner, J. (1966). Toward a theory of instruction. Cambridge, MA; Harvard University Press.

Bruner, J. (1996). The culture of education. Cambridge, MA: Harvard University.

Cooper, H., Robinson, J., \& Patall, E. (2006). Does homework improve academic achievement: A synthesis of research. Review of Educational Research, 76, 1-62. doi:10.3102/00346543076001001

Darling-Hammond, L. (2000). Teacher quality and student achievement. Education Policy Analysis Archives, 8, 1-44.

Diamond, A., \& Lee, K. (2011). Interventions shown to aid executive function development in children 4 to 12 years old. Science, 333, 959-964. doi:10.1126/science.1204529

Doidge, N. (2007). The brain that changes itself: Stories of personal triumph from the frontiers of brain science. Toronto, CA: Penguin.

Goe, L, \& Stickler, L. (2008). Teacher quality and student achievement: Making the most of recent research. TQ Research \& Policy Brief. URL (last checked 28 December 2011).

www.tqsource.org/publications/March2008rief.pdf

González, N., Andrade, R., Civil, M., \& Moll, L. (2001). Bridging funds of distributed knowledge: Creating zones of practice in mathematics. Journal of Education of Students Placed at Risk, 6, 115-132. doi:10.1207/S15327671ESPR0601-2_ 7

Hanusek, E., Kain, J., O’Brien, D., \& Rivkin, S. (2005). The market for teacher quality. Working Paper $n$. 11154. Cambridge, MA: National Bureau of Economic Research. URL) last checked 28 December 2011). www.nber.org/papers/w11154.pdf

Hmelo-Silver, C. E., Duncan, R. G., \& Chinn, C. A. (2007). Scaffolding and achievement in problem-based and inquiry learning: A response to Kirschner, Sweller, and Clark, 2006. Educational Psychologist, 42, 99-107. doi:10.1080/00461520701263368

Kalantzis, M., \& Cope, B. (2008). New learning: Elements of a science of education. Cambridge, MA: Harvard University Press.
Knowles, M. (1980). The modern practice of adult education: From pedagogy to andragogy. Chicago, IL: Follet.

Lave, J., \& Wenger, E. (1991). Situated learning: Legitimate peripheral participation. Cambridge: Cambridge University Press.

Lowenfeld, V., \& Brittain, W. L. (1975). Creative and mental growth (6th edition). New York, NY: MacMillan.

Marcon, R. (2002). Moving up the grades: Relationship between preschool model and later school success. Early Childhood Research and Pratice, 4. URL (last checked 20 January 2010). http://ecrp.uiuc.edu/v4n1/marcon.html

McEwen, B., Aki, H., Barchas, J., \& Kreek, M. (Eds.) (2011). Social neuroscience: Gene, environment, brain, body. Annals of the New York Academy of Science, 1231.

Newell, A., \& Simon, H. (1972). Human problem solving. Englewood Cliffs, NJ: Prentice Hall.

Papert, S. (1980). Mind storms. New York: Basic Books.

Papert, S., \& Harel, I. (1991). Constructionism. Norwood, NJ: Ablex Publishing.

Pascual-Leone, A., Amedi, A., Fregni, F., \& Merabet, L. B. (2005) The plastic human brain cortex. Annual Review of Neuroscience, 28, 377-401. doi:10.1146/annurev.neuro.27.070203.144216

Pea, R. (2004). The social and technological dimensions of scaffolding and related theoretical concepts for learning, education, and human activity. Journal of the Learning Sciences, 13, 423-451. doi:10.1207/s15327809jls1303 6

Piaget, J. (1975). Equilibrium of cognitive structures. Chicago, IL: University of Chicago Press.

Piaget, J. and Kegan, P. (1957). Construction of reality in the child. London: Routledge.

Scardamalia, M., \& Bereiter, C. (1991) Higher levels of agency for children in knowledge building: A challenge for the design of new knowledge media. Journal of the Learning Sciences, 1, 37-68. doi:10.1207/s15327809jls0101_3

Schauble, L. \& Glaser, R. (Eds.) (1996). Innovations in learning: New environments for education. Mahwah, NJ: Erlbaum.

Sherin, B., Reiser, B., \& Edelson, D. (2004). Scaffolding analysis: Extending the scaffolding metaphor to learning artifacts. Journal of the Learning Sciences, 13, 387-421. doi:10.1207/s15327809jls1303_5

Scott-Jones, D. (1995). Parent-child interactions and school achievement. In B. A. Ryan, G. R. Adams, T. P. Gullota, R. P. Weissberg, \& R. L. Hampton (Eds.), The family-school connection: Theory, research, and practice (pp. 75-107). Thousand Oaks, CA: Sage.

Van Voorhis, F. (2003). Interactive homework in middle school: Effects on family involvement and science achievement. Journal of Educational Research, 96, 323-338. doi:10.1080/00220670309596616

Verenikina, I. (2010). Vygotsky in twenty-first-century research. World Conference on Educational Multimedia, Hypermedia and Telecommunications 2010. URL (last checked 21 September 2010). http://research.kinasevych.ca/2010/07/verenikina-2010-vygotsky-in-t wenty-first-century-research/

Vygotsky, L., \& Kozulin, A. (Eds.) (1986). Thought and language. Cambridge, MA: MIT Press.

Wertsch, J. (1985). Vygotsky and the social formation of mind. Cambridge, MA: Harvard University Press.

Wishy, B. (1972). The child and the republic. Philadelphia, PA: University of Pennsylvania. 